\title{
NARRATING EDUCATION: THE ROLE OF WRITING PRACTICES IN THE PROFESSIONAL DEVELOPMENT OF EDUCATORS
}

\author{
Elisabetta Biffi \\ University of Milano-Bicocca, Italy
}

\begin{abstract}
The professional development of those who work in the educational sector is a theme that is widely debated at the European level. It is related to the need to guarantee high standards of educational work and high quality educational services. This paper addresses the theme from the viewpoint of the writing practices and documenting of educational work carried out by educators. Independently of the specific educational context, these professionals are called on to narrate their work, especially in written form, both as an internal record, and to externally communicate the meaning of their actions in the area where the service is based and to other stakeholders. The theory explored by the current paper is that the act of writing up their own educational work is also a valuable means of enhancing educators' professional development.
\end{abstract}

Keywords: writing practices, documentation, professional development, educational work

\section{Telling educational work}

Education takes place in a range of contexts and involves multiple professional figures. Education professionals are employed in educational services but also in social, welfare and health services, in roles that vary in line the specific local context and regulatory framework. Such variation occurs both within countries and from one country to another. The very term "educational work," for instance, does not even hold the same meaning in all the European countries, in which educators may be referred to as teachers, social-workers, caregivers, and so on, though having similar operational roles.

Thus, the current reflection regards all professionals operating in educational, social-work, welfare and care contexts with a broad range of educational responsibilities, because the educational characteristics of their work is what all of these figures have in common, and what prompts reflection on documentation practices as a resource for professional development.

In the first place, educational work is always relational: whether it is carried out directly with the end users of an educational service, or whether it is conducted with professionals (in the case of training, counseling or supervision). In both cases, the education professional is required to relate to other subjects, and this relationship becomes the primary instrument and medium for intervention. Therefore, educational work demands total engagement on the part of the professional, at both the cognitive and the emotional and affective levels, as does any job that is principally carried out in the context of interpersonal relationships.

Secondly, educational work - by definition - involves intervention: the educator "invades" - either because directed to do so by the educational service or 
because requested to do so by the client - a pre-existing situation in the other person's life, with the aim of activating particular educational processes. In other words, educational work has the goal of changing the status quo. Including when the desired change is, "only", the natural development of the clientsubject, such as in early childhood education. At the same time, however, when change involves existential, personal and social dimensions as in the case of educational work, it can never be effected in a short time-span: it requires a long-term perspective and the concurrent interaction of a range of variables not all of which are under the direct control of the educator. An example of this would be educational work carried out in the context of child protection, which aims to bring a systemic approach to bear on the entire family. In this type of context, the opportunity to intervene in the educational relationship with the minor is a necessary but insufficient condition: further intervention is required at the level of the family network, but this depends in part on other actors who also have a stake in the process (at the social, legal, economic or other levels).

It follows that the change enacted and aimed for in the educational intervention is a complex affair, which exceeds the limits of the educational relationship between provider and client. Indeed, the educational intervention is designed to last a fixed length of time (it cannot go on indefinitely), while the change activated in the context of the intervention may very well need a longer time. It is easier to understand this if we reflect on our own history: we have all gone through realizing that a certain experience was educational only some time after it was over. Finally, given that education is usually carried out in the context of a network of relations, as mentioned above, education professionals rarely operate in isolation, in organizational and institutional terms, even when their daily work involves intervening on a one-to-one basis with the client. Thus it is fundamental for them to be able to share the meaning of their own relational work with the other reference figures interacting in the situation, from the family - in the case of early childhood education - to health and medical professionals - in a range of care contexts - to social-work and legal professionals - in the case of child protection - and so on.

These same characteristics of educational work, make it all the more important and necessary for education professionals to be able to keep a record of their own professional activities, to document their own interventions in order to cater for a series of needs: that of stimulating their professional reflection on their own activity, that of monitoring the process throughout its longer-term development, and that of communicating the situation to the other key figures with a role in it.

Practices of documenting educational work fulfill these basic functions, through modes and procedures that vary in line with the professional's institutional and organizational context. Indeed documentation is used by all organizations and institutions both for memory and for procedural purposes. The document, once written, becomes an "act" or "record" with legal and institutional value, which 
translates operational practice into official procedure. This, as Maurizio Ferraris has observed (2009), is a specific requirement of all societies and collectivities. In my reflection here, I set out to explore the factors that make this process of documentation, of recording one's daily work, a resource for professional development. Underpinning my perspective is the recognition that writing practice is a key knowledge-building process. And this is the aspect that I examine in the next section.

\section{Writing as a knowledge-building practice}

Focusing now on the relationship between writing and knowledge, we should note that the concept of thought as the logos, or structured discourse, to which writing refers, first took hold within the philosophical tradition of Ancient Greece. If, as Hanna Arendt claims, we cannot imagine thoughts without words (Arendt, 1978), then equally the logos is the discourse into which words are combined to form phrases with an overall meaning (ivi). Thus, thoughts need words not only to be express themselves but also to produce the world. Proof of this is the existence of words that are only valid and recognizable for particular groups of people - outside of these groups they lack meaning and are incomprehensible because they have no use.

The creative power of writing continued to evolve over the centuries, to the point of becoming a recognized philosophical exercise. In the $1^{\text {st }}$ and $2^{\text {nd }}$ centuries A.D., to be exact, writing became an integral part of the exercise of the self developed by thinkers such as Seneca and Marcus Aurelius, in their version of the Stoicism that in an more ancient era had been inspired by the thinking of Socrates. For these philosophers, writing became an essential instrument for the self-care referred to in Socrates' epimeleia heautou, itself too often forgotten. Essential because it facilitated that intimate dialogue with oneself, which to some degree, had not found fertile ground in earlier historic periods. The key example of the use of writing as a philosophical exercise may be found in Marcus Aurelius' Meditations, a work composed of the hypomnémata, cautions, exhortations and dogmata, that the philosopher-emperor addressed to himself in his inner dialogue. However, it was not a matter of simply writing them so as to keep them in mind, that is to say writing was not used solely as an aid to memory: it was a matter of making these meditations into a means of raising consciousness (Hadot, 1995). Thus writing was chosen on account of its power to generate thought and simultaneously to bring the world into itself; as suggested by Michel Foucault, thanks to the mere fact of writing we make our own of the thing we are thinking about (Foucault, 2001). Reading back over one's writing was not enough: it was necessary to rewrite several times, to reproduce the thought until the cautions issued to oneself became a way of life. And so, writing became one of the philosophical exercises, understood as voluntary and personal practices (Hadot, 1995). 
This is why thinking, in the current understanding of creative thought guiding human action, demands writing: "We may only speak appropriately and sensibly about thought through the transfiguration of the gesture of writing, which immobilizes discursive practice and translates it into a solid body" (Sini, p. 52). This same solidity is also referred to by Maria Zambrano, when she claims that writing becomes the opposite of speaking: we speak to satisfy a passing need, while writing is only liberating when we succeed in producing something lasting (Zambrano, 1950).

Thus writing is construction of thought, and consequently construction of the meaning that each of us attributes to the world. Thus we come back to the productive nature of writing, the making solid just mentioned above, which allows us to objectify our thinking, and therefore to question its meaning and truth value, something which is difficult to do with pure orality given its precariously instantaneous nature.

\section{Writing about our own work in order to develop our thinking on our profession}

As stated at the outset, educational work involves rich and highly complex intervention, requiring not only specific disciplinary knowledge, but also relational, reflective and self-reflective competence on the part of the educator. These competencies may be promoted through the practice of writing, whose educational value when appropriately drawn out, can make an extremely useful instrument for educators.

In the first place, as already pointed out, key concerns in educational work are the educational process and the development of clients' personal capacities, and this implies a significant investment in thinking, both in terms of the educator's own thinking and in terms of helping the client to think; and in this sphere, as I set out to discuss here, writing can be a valuable resource and a means of activating critical reflection. Secondly, writing lends itself to providing education professionals with their own personal space in which to reflect on their own role and intervention, and in which they can work on their own emotions and attributions of meaning; therefore writing about their work can also act as a form of ongoing self-monitoring, a space devoted to keeping an eye both on the self and on the status of the educational process. These are very important aspects which legitimate and qualify the use of writing practice not just as a means of documenting what has happened, but also a means of reflecting on one's own work in order to reinterpret and revise it, both during an intervention and afterwards, in a progressive reflection which may even lead to rethinking one's next project.

However, documenting one's work means not only writing about oneself but also about the other. Indeed in many cases, unfortunately, the writing up of educational work translates into writing about the other, with the educator's 
intervention all but disappearing. This is a risk to remain vigilant against, both because it implies that responsibility for the process is attributed de facto to the end user - such and such a thing happened because he/she is just like that - and because it also implies that the educator forgoes the opportunity to give voice to his or her work, to draw out its value and meaning.

Thus, writing to document educational work means taking into account the life stories of the subjects involved, and consciously adopting a hermeneutic approach to situations presented as problematic. Only in this way, can education professionals benefit from writing practice as a resource, developing their thinking about their actions and in their actions, as emphasized by D.A. Schön (1987).

All of this explains why in the training of education professionals ample use is made of forms of professional writing that promote processes of reflection on action. For example, we may cite the French-speaking tradition of écrits professionnels (Cifali, 1996; Cifali \& André, 2007; Crognier, 2011; MercatMaheu, 2010; Oriol-Boyer \& Bilous, 2013) and the Italian tradition of writing in educational training, which can follow different schools of thought (Biffi, 2013; Canevaro, Chiantera, Cocever \& Perticari, 2000; Demetrio, 2007)

Thus writing up our educational work allows us to think critically about our actions through conscious analysis of the framework of meaning that J. Mezirow (1991) defines as the structure of psychological and cultural assumptions within which our past experience assimilates and transforms our current experience. In order to think, in the sense of searching for the meaning of the experience we are having, it is not enough to look to well-established scientific theories: we also need to bring to bear our own epistemological framework, that is to say our own personal mode of constructing knowledge. We therefore need to recognize the "local theories" that allow each of us to construct our own theory of the world, and therefore also of the specific educational crisis that we are dealing with. In conclusion, writing up educational work consists of leading educators to reflect on how they have constructed their own vision of the facts and to problematize the underlying theories, thereby enhancing their capacity to see the problem in an alternative light.

Thus, constructing knowledge on the basis of experience means replacing top down logic, with a form of logic that operates from the ground up, whereby practice becomes the place in which knowledge is constructed (Mortari, 2003). However, such a reflection process does not only comprehend the facts, the data available to us, but also the emotional and affective aspects that are part of the subjects' life stories; the way in which each of us constructs knowledge depends on the way that we think, in other words, on ourselves and on our stories. Thus, educators must reflect on their own actions in relation to their clients considered in terms of the latters' global identity and stories of life experience. In other words, the writing process not only concerns the level of action, but also that of the personal meanings attributed to action, because by "pressing the keys" of 
metacognition, it leads educators to experience different ways of thinking, which inevitably lead in turn to different ways of thinking of themselves.

\section{Conclusions}

Throughout this complex reflexive process-path, the narrative inherent in writing becomes an appropriate and dedicated instrument for giving voice to and integrating the different levels concurrently present in the situation: the levels of the problem, the subjects, the relationships; as in the thinking of J. Bruner, narrative allows us to structure experience, because narrative is thought itself, in which we may identify the truth of the narrating subject: the Self as narrator does not only tell, rather it sets out to justify (Bruner, 1990), or demonstrate, its own theory of the world and its own story. Narrative is therefore an intimate and personal search for the right and most meaningful words to shape one's own thoughts; the narrator brings to bear the patience of a composer who links together individual sounds, interspersed with appropriate pauses, in the quest for a harmony that can only be appreciated when it has been fully completed. To narrate, therefore, the subject must draw on the maieutic power - the power to create - of words. Words which only have meaning in the context of an overall complex narrative, words whose composition creates and raises to consciousness lived experiences, which if they were to go un-narrated would no longer be remembered (Demetrio, 2012).

All of these principles may be appropriately applied to the writing up of educational work, in which narrated thoughts become manifest, traceable and accessible. Thus writing about their own work allows education professionals to go back over the course of their own reflections, the genesis of their theories and intervention, thereby becoming a valuable tool for their professional development. Writing in order to document their own work means creating an internal space - and an external one, in that writing involves the physical and material effort of sitting down, taking up a pen and putting it to a blank sheet of paper - dedicated to personal work on their professional choices, facilitating the formation of alternative perspectives on the situations in which they are required to intervene. Thus writing becomes the space of the possible, of saying things differently, of reflectively experimenting with what, in real space, may be possible to realize.

Thus, the documenting of educational work becomes the space in which events may be analyzed, a space which however reflects the educator's own subjective perceptions and viewpoint, in terms of how he or she writes, in terms of the style, works, emphases and pacing of the narrative. And which, at the same time, is called on to engage with the viewpoints and accounts of others, in the first place with those to whom the writing is addressed, the coordinator, a colleague who is working on the same case, the doctor or psychologist who is providing 
care for the subject, the judge called upon to make decisions on the case and so on.

And so, the writing up of educational work becomes both a private and personal practice for educators, and a public action and form of intervention with the aim of bringing educators back out of the one-to-one relational space in which their educational work is carried out on a day-to-day basis. It takes them back to their original mission, social and public, fostering reflection on the network dimension of educational intervention which is of critical importance to educators and their professional development.

\section{References}

1. Arendt, H. (1987). The Life of the Mind. New York: Harcourt Brace Jovanovich.

2. Biffi, E. (2013). Narratives Practices for Counselling in Educational Context. In Society, Integration, Education. Proceeding of the International Scientific Conference (pp.194-202). Rezekne.

3. Bruner, J. (1990). Act of Meaning. Cambridge, MA: Harvard University Press.

4. Canevaro, A., Chiantera, A., Cocever, E. \& Perticari, P. (2000). Scrivere di educazione. Roma: Carocci.

5. Cifali, M. (1996). Transmission de l'expérience, entre parole et écriture. In Education permanente. 22 (127), p. 183-200.

6. Cifali, M. \& André, A. (2007). Écrire l'experiénce. Paris: PUF.

7. Crognier, P. (2011). Précis d'ecriture en travail social. Des ateliers d'écriture pour se former aux écrits professionnels. Paris: Edf Editeur.

8. Demetrio, D. (2012) (a cura di). Educare è narrare. Milano: Mimesis.

9. Demetrio, D. (a cura di). (2007). Per una pedagogia e una didattica della scrittura. Milano: Unicopli.

10. Ferraris, M. (2009). Documentalità. Perchè è necessario lasciar tracce. Roma-Bari: Laterza.

11. Foucault, M. (2001). L'herméneutique du sujet: Course au Collège de France 19811982. Paris: Editions du Seuil-Gallimard.

12. Hadot, P. (1995). Qu'est-ce que la philosophie antique?. Paris: Gallimard.

13. Mercat-Maheu, I. (2010). Histoires d'écritures. Voyage en atliers d'écriture. Paris: La Cause des Livres.

14. Mezirow, J. (1991). Transformative Dimensions of Adult Learning. San Francisco: Jossey-Bass.

15. Mortari, L. (2003). Apprendere dall'esperienza. Il pensare riflessivo nella formazione. Roma: Carocci.

16. Oriol-Boyer, C. \& Bilous, D. (2013). Ateliers d'écriture littéraire. Paris: Éditions Hermann.

17. Schön, D.A. (1987). Educating the Reflective Practitioner: Toward a New Designfor Teaching and Learning in the Professions, San Francisco: Jossey-Bass.

18. Sini, C. (1992). Etica della scrittura. Milano: Mondadori.

19. Zambrano, M. (1950). Hacia un saber sobre el alma. Buenos Aires: Losada.

Elisabetta Biffi
"Riccardo Massa" Department of Educational Human Sciences University of Milano-Bicocca

e-mail: elisabetta.biffi@unimib.it, tel.: +390264484859 